\title{
Expression of Stress-Response Proteins Upon Whitefly-Mediated Inoculation of Tomato yellow leaf curl virus in Susceptible and Resistant Tomato Plants
}

\author{
Rena Gorovits, Fouad Akad, Hila Beery, Favi Vidavsky, Assaf Mahadav, and Henryk Czosnek \\ Institute of Plant Sciences and Genetics in Agriculture and the Otto Warburg Minerva Center for Agricultural Biotechnology, \\ Faculty of Agriculture, The Hebrew University of Jerusalem, Rehovot 76100, Israel
}

Submitted 9 May 2007. Accepted 23 June 2007.

\begin{abstract}
To better understand the nature of resistance of tomato to the whitefly (Bemisia tabaci, B biotype)-transmitted Tomato yellow leaf curl virus (TYLCV), whiteflies and TYLCV were considered as particular cases of biotic stresses and virus resistance as a particular case of successful response to these stresses. Two inbred tomato lines issued from the same breeding program that used Solanum habrochaites as a TYLCV resistance source, one susceptible and the other resistant, were used to compare the expression of key proteins involved at different stages of the plant response with stresses: mitogen-activated protein kinases (MAPKs), cellular heat shock proteins (HSPs, proteases), and pathogenesis-related (PR) proteins. The two biotic stresses-nonviruliferous whitefly feeding and virus infection with viruliferous insects-led to a slow decline in abundance of MAPKs, HSPs, and chloroplast protease FtsH (but not chloroplast protease $\mathrm{ClpC}$ ), and induced the activities of the PR proteins, $\beta$-1,3-glucanase, and peroxidase. This decline was less pronounced in virus-resistant than in virussusceptible lines. Contrary to whitefly infestation and virus infection, inoculation with the fungus Sclerotinia sclerotiorum induced a rapid accumulation of the stress proteins studied, followed by a decline; the virus-susceptible and -resistant tomato lines behaved similarly in response to the fungus.
\end{abstract}

Wild ancestors of domesticated agricultural plants are well adapted to many kinds of environmental stresses and a wide range of pathogens. During breeding for high yield and good fruit quality, many of the alleles conferring resistance to stress have been lost. As a result, domesticated agricultural crops are susceptible to many environmental stresses. Wild germplasm has been used to regain stress resistance and improve horticultural qualities. By crossing domesticated crops with their wild relatives and selecting for both horticultural quality and stress resistance, breeders have succeeded in introgressing chromosomal fragments from wild species that contain stress-resistant genes into superior lines and hybrids (Rick 1976; Zamir and Eshed 1997).

The whitefly Bemisia tabaci transmits a variety of begomoviruses to tomato worldwide, dramatically reducing yields (Czosnek and Laterrot 1997). Breeding for resistance to begomoviruses infecting tomato, such as Tomato yellow leaf curl

Corresponding author: H. Czosnek, E-mail: czosnek@agri.huji.ac.il virus (TYLCV), consists of introgressing into the domesticated tomato (Solanum lycopersicum) the resistant traits from wild tomato species such as Solanum chilense, Solanum peruvianum, and Solanum habrochaites. Several tomato lines have been developed with various levels of tolerance to TYLCV. Depending on the wild source, resistance is conferred by one to five loci (Lapidot and Friedmann 2002). The genes and, consequently, proteins conferring resistance to TYLCV and their mode of expression in the establishment of the resistance phenotype are totally unknown.

During a breeding program for TYLCV resistance, two inbred tomato lines were developed, the TYLCV-susceptible line 906-4 (RT) and the TYLCV-resistant line 902 (SF), with resistance introgressed from Solanum habrochaites (Vidavsky and Czosnek 1998). To better understand the nature of resistance of tomato to TYLCV, whiteflies and TYLCV were considered as particular cases of biotic stresses and virus resistance as a particular case of successful response to stress. Several classes of key stress proteins are known to be involved at different stages in plant responses to many different biotic and abiotic stresses: the mitogen-activated protein kinase (MAPK) cascades, the heat shock protein (HSP) families, and pathogenesis-related (PR) proteins.

The MAPK cascades are universal signal transduction pathways found in eukaryotes (Roberts et al. 2000). MAPKs are present in higher plants and play an important role in regulation of response to hormones, biological signals, and environmental stresses (Hirt 1997; Yuasa et al. 2001). Evidence is accumulating that MAPK cascades also are involved in signal transduction leading to activation of plant defense against fungal, microbial, and viral attacks (Nuhse et al. 2000; Desikan et al. 2001).

A group of highly conserved proteins, termed HSPs (chaperones and proteases), has evolved to cope with environmental stresses. They play a crucial role in protecting plants against biotic and abiotic stresses by reestablishing cellular homeostasis and interacting with a wide range of co-chaperones and proteases (Boston et al. 1996; Sun et al. 2002; Sung and Guy 2003; Wang et al. 2004). HSPs control protein integrity in almost all cellular compartments by folding proteins and refolding denatured proteins, by preventing aggregation, by transport, and by proteolytic degradation (Grover 2002; Sherman and Goldberg 2001). Protein degradation can occur in different compartments of the plant cell. The chloroplast-localized ClpC protease, the chloroplast ATP-dependent metalloprotease $\mathrm{FtsH}$, and several other protease families are responsible for most 
protein degradation within the stroma (Adam and Clarke 2002). Up to now, FtsH is the only chloroplast protease thought to be implicated in response to virus (Tobacco mosaic virus [TMV]) infection (Seo et al. 2000).

Most of the plant defense-related proteins relate to PR proteins or to the products of so-called systemic acquired resistance (SAR) genes, and appear in both compatible and incompatible plant-pathogen interactions (Pieterse and Van Loon 1999; van Loon 1999). PR proteins have been reviewed extensively (van Loon et al. 2006) and currently comprise 17 families of stress proteins, among them $\beta$-1,3-glucanases, chitinases, and peroxidases.

Hence, the expression of these key proteins was followed upon whitefly-mediated inoculation of TYLCV in the RT and SF lines, and in a commercial susceptible cultivar with a different genetic background (cv. Daniella, 144). It was found that, upon infestation with nonviruliferous whiteflies (mockinoculation) and viruliferous whiteflies (TYLCV inoculation), the variation in stress-response proteins were less pronounced in RT than in SF (and 144) genotypes.

\section{RESULTS}

Changes in MAPK patterns in resistant and susceptible tomato genotypes upon infestation with nonviruliferous whiteflies (mock inoculation) and viruliferous whiteflies (TYLCV inoculation).

Based on sequence analysis, the known plant MAPKs are most similar to mammalian extracellular signal-regulated kinases (ERKs). Compelling evidence implies ERKs in various forms of biotic and abiotic stress responses (Bogre et al. 2000). Phospho-ERK antibodies raised against synthetic phosphopeptide derived from human ERKs recognize polypeptides with molecular mass of 45 to $50 \mathrm{kDa}$ in tomato protein extracts (Fig. 1). Antibodies against the nonphosphorylated protein also were tested. In the later case, the signal was barely detectable (data not shown). Therefore, the signal seen in Figure 1 represents activated ERK-like proteins. The patterns of ERK-like proteins in the RT and SF tomato genotypes, and in a genetically unrelated susceptible cultivar (144), were com- pared before (C) and up to 40 days postinfestation (dpi) with nonviruliferous (mock inoculation, Wf) and with viruliferous whiteflies (V). OE33 (33-kDa subunit of oxygen-evolving system of photosystem II), detected by a polyclonal antibody, was used as an internal protein marker (Fig. 1). The pattern of this protein did not change when plants were submitted to whitefly feeding and whitefly-mediated inoculation of virus until 50 to 60 dpi. At 1 dpi, ERK patterns did not change compared with untreated control. At 5 to 7 and 10 to $15 \mathrm{dpi}$, a decrease in ERK amounts was observed in plants caged with nonviruliferous and viruliferous insects. The virus by itself did worsen the effects induced by whitefly feeding on the 144 and SF lines. At $30 \mathrm{dpi}$, some recovery of the ERK-like protein was detected (Fig. 1). In the case of RT plants, the decrease in ERK-like protein abundance was less pronounced than in SF tomato. The commercial line 144 behaved like SF. It has to be noted that the changes in ERK-like protein abundance took place before the appearance of TYLCV disease symptoms (not earlier than after 4 to 5 weeks after inoculation). It also has to be mentioned that, during the time course of the experiment, an aging-related decrease in the total amount of cellular proteins per leaf fresh weight was observed in parallel with the decrease in abundance of ERK-like proteins (as indicated by Coomassie staining; not shown). Hence, the modulation of ERKs patterns was compared in treated (Wf or $\mathrm{V}$ ) and untreated leaves of the same age $(\mathrm{C})$.

Expression of two other MAPK families, detected by antibodies raised against mammalian JNK and P38 kinases, has been assayed. Changes in these MAPK levels were less pronounced in RT than in SF or 144 genotypes after infestations with viruliferous and nonviruliferous whiteflies (data not shown). Viruliferous and nonviruliferous whiteflies had similar effects on the patterns of MAPK-like proteins.

\section{Changes in HSP patterns in resistant and} susceptible tomato genotypes upon whitefly-mediated TYLCV inoculation and mock inoculation with nonviruliferous whiteflies.

HSPs (chaperones and proteases) play a crucial role in protecting plants against stress by reestablishing cellular homeo-

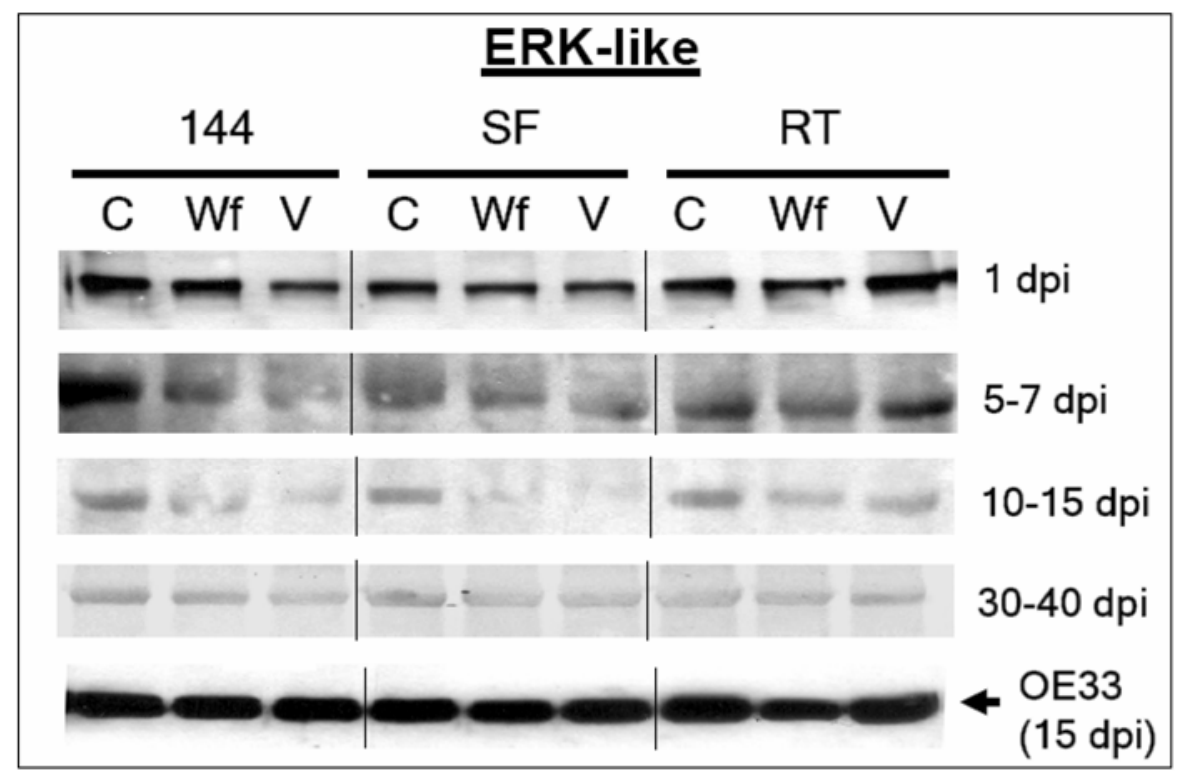

Fig. 1. Mammalian extracellular signal-regulated kinase (ERK)-like protein patterns in susceptible (144 and SF) and resistant (RT) tomato plants following whitefly-mediated infestation. C: untreated, Wf: infestation with nonviruliferous whiteflies, V: infestation with viruliferous whiteflies. Western blot analyses of proteins extracted from tomato leaves and immunodetected with anti-ERK antibodies. OE33 (33-kDa subunit of oxygen-evolving system of photosystem II) was used as an internal protein marker; dpi: days postinfestation. 
stasis upon stress. The patterns of various HSPs in the RT and SF or 144 tomato genotypes have been studied using polyclonal antibodies that detect several main chaperone classes: HSP60, HSP70, and HSP90 (Fig. 2). The patterns of cellular HSPs before (C) and after mock- (Wf) and virus- (V) inoculation, up to 30 to $40 \mathrm{dpi}$ (60 dpi for HSP70) were analyzed to determine whether whitefly-induced biotic stresses influenced HSP levels. At 5 to $7 \mathrm{dpi}$, a decrease in the abundances of all three HSPs was observed in the susceptible SF and 144 but not in resistant
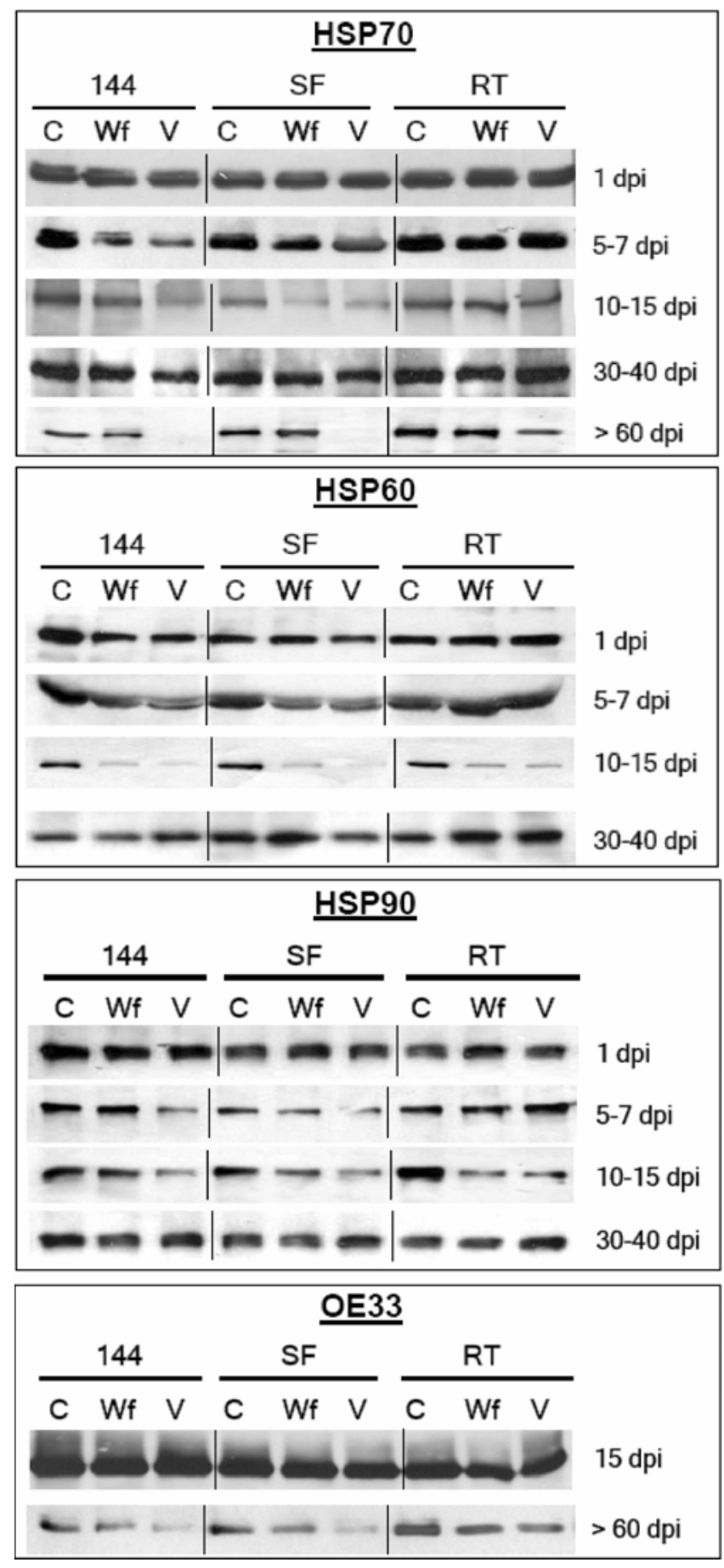

Fig. 2. Heat shock proteins (HSP70, HSP60, and HSP90) in susceptible (144 and SF) and resistant (RT) tomato plants following whitefly-mediated infestation. C: untreated, Wf: infestation with nonviruliferous whiteflies, $\mathrm{V}$ : infestation with viruliferous whiteflies. Proteins were immunodetected with anti-Hsp70/Hsc70, anti-Hsp60 and anti-Hsp90; OE33 was used as an internal protein marker. dpi: days postinfestation.
RT plants treated with viruliferous or nonviruliferous insects, well before appearance of disease symptoms. At 10 to $15 \mathrm{dpi}$, the abundance of HSP70 continued to decrease in SF and 144, but not in RT plants; in comparison, the abundance of HSP60 decreased also in RT plants, but to a lesser extent, whereas that of HSP90 decreased in all three lines in a similar fashion. At these early stages after infestation, the presence of the virus caused an additional decline in the abundance of HSPs, best seen with HSP70 and HSP90 in 144 and SF tomato. Similar to the behavior of the ERK-like proteins, HSP levels recovered at 30 to $40 \mathrm{dpi}$. At $60 \mathrm{dpi}$ and longer, HSPs almost completely disappeared in 144 and SF tomato treated with viruliferous whiteflies (shown for HSP70), coinciding with a decline in the amount of total proteins (see marker protein, OE33) associated with strong virus-induced symptoms. In RT plants, this decrease was less pronounced, probably because the plants did not show disease symptoms.

Together with HSP70, HSP60, and HSP90, the patterns of two chloroplast stroma ATP-dependent proteases, ClpC and $\mathrm{FtsH}$, have been followed. So far, FtsH is the only chloroplast protease shown to be involved in response to virus infection (Seo et al. 2000). ClpC protein levels were similar in tomato infested with nonviruliferous whiteflies and with viruliferous whiteflies, during long periods (shown for the first 2 weeks after treatment) (Fig. 3). In comparison, the pattern of FtsH was quite different and resembled that of HSP70. A decline in FtsH amounts was observed at 5 to $7 \mathrm{dpi}$ and 10 to $15 \mathrm{dpi}$ in 144 and SF plants, whereas the amounts of OE33 did not change (Fig. 3). In SF and 144 plants, virus infection enhanced the effect of whitefly feeding. In comparison, the patterns exhibited by RT plants were more stable. At 60 dpi, there was a marked decrease in the amounts of both proteases, associated with the development of disease symptoms in virus-infected SF and 144 tomato, coinciding with a decrease in the total amount of proteins as reflected by the pattern of OE33 (Fig. 2).

Changes in PR enzyme activities: chitinase, $\beta$-1,3-glucanase, and peroxidase in resistant and susceptible tomato genotypes upon whitefly-mediated TYLCV inoculation and mock inoculation with nonviruliferous whiteflies.

It has been shown previously that heavy whitefly infestation of tomato plants was accompanied by the accumulation of the PR proteins chitinase, $\beta$-1,3-glucanase, and peroxidase (Mayer et al. 1996). However, when plants were inoculated with small numbers of insects harboring Tomato mottle virus (ToMoV), the PR proteins accumulated in the infected tomato leaves, but not in the leaves mock inoculated with nonviruliferous whiteflies (McKenzie et al. 2002).

The activities of chitinase, $\beta$-1,3-glucanase, and peroxidase in tomato leaves infected with nonviruliferous (Wf) and viruliferous (V) whiteflies were followed from 1 day until 2 months after infestation (Fig. 4). The activity of all three enzymes in leaves of untreated control (C) plants increased with time. This increase, which might be related to plants aging, was statistically significant $(P<0.0005)$. Insect and virus treatments led to a small increase in chitinase activity after 40 to 50 dpi (three to four times the basal levels in control leaves; discussed below). In contrast, a pronounced increase in $\beta$-1,3-glucanase activity was correlated with whitefly feeding, starting at $28 \mathrm{dpi}$ and amplifying thereafter (12 to 15 times the level in control leaves and 2.5 to 3 times the level in aged untreated leaves). It has to be noted that viruliferous and nonviruliferous whiteflies had similar effects. Susceptible (SF and 144) and resistant (RT) plants presented similar patterns of chitinase and $\beta$-1,3-glucanase activities upon treatments. 
The pattern of peroxidase activity was quite different: virussusceptible tomato (SF and 144) presented higher activity that virus-resistant tomato (RT) in response to infestation with viruliferous whiteflies. SF and 144 leaves challenged with viruliferous whiteflies showed a level of peroxidase significantly higher (6 to 12 times the level in control leaves and, most importantly, 2 to 3 times the level in leaves inoculated with whitefly) than that in uninfected control plants or plants mock inoculated at $42 \mathrm{dpi}$ and thereafter. The higher peroxidase activity in 144 than in SF plants at 42 and 60 dpi was not statistically significant $(P<0.1316)$. The presence of TYLCV was associated with the elevation of peroxidase activity in susceptible but not in resistant tomato plants. The activity of this PR protein may reflect the massive TYLCV disease symptoms in susceptible leaves compared with the absence of symptoms in resistant tomato plants.

Changes in PR enzyme activities, ERK-like, proteins and HSPs patterns in TYLCV-resistant and -susceptible tomato genotypes upon Sclerotinia sclerotiorum inoculation.

Plant responses to the penetration of the stylets of phloemfeeding insects have been compared with fungal hyphae penetrating plant cells (Fidantsef et al. 1999; Zhu-Salzman et al. 2004). Sclerotinia sclerotiorum inoculation was used in this study as a particular case of fungal attack. Contrary to the symptoms in tomato caused by viruliferous whiteflies (conspicuous
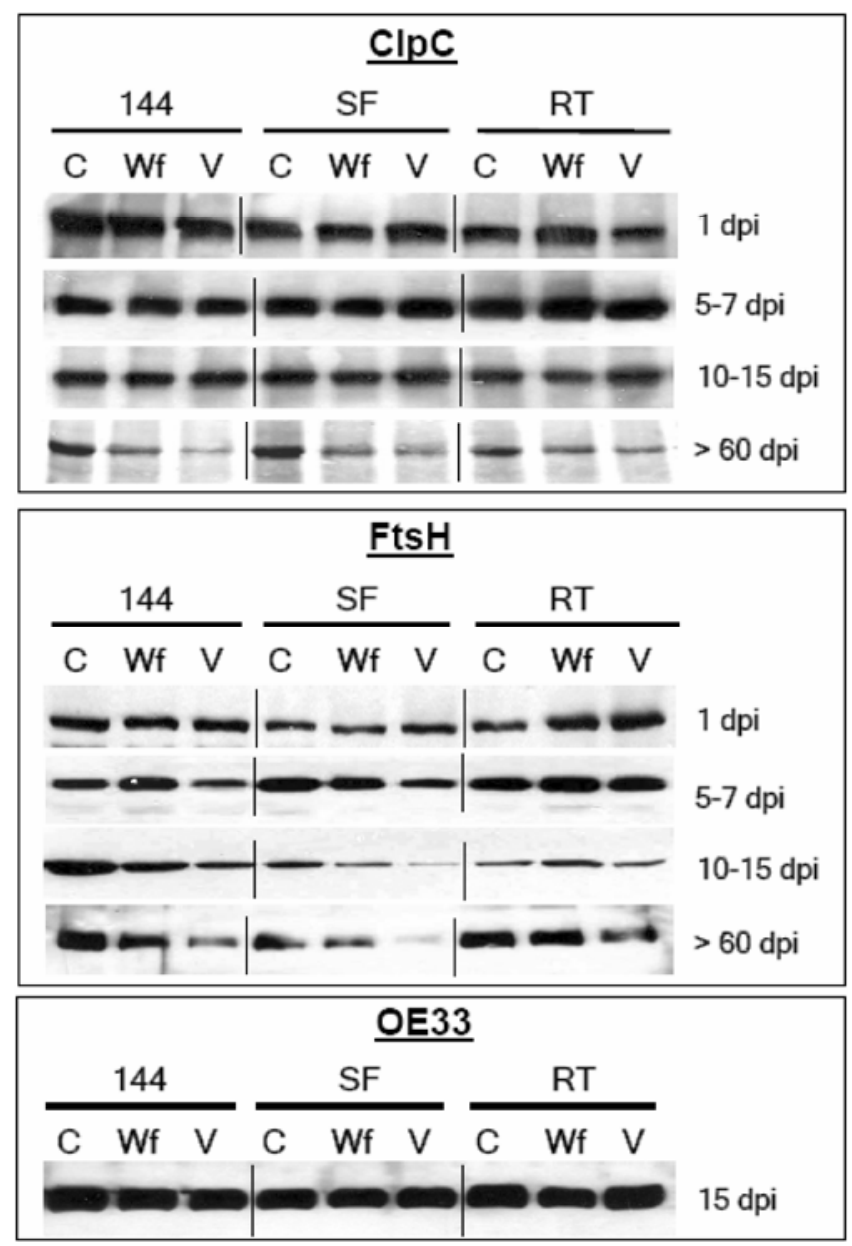

Fig. 3. Proteases ( $\mathrm{ClpC}$ and $\mathrm{FtsH})$ in susceptible (144 and $\mathrm{SF})$ and resistant (RT) tomato plants following whitefly-mediated infestation. C: untreated, Wf: infestation with non-viruliferous whiteflies, V: infestation with viruliferous whiteflies. Proteins were immunodetected with anti-ClpC and anti-FtsH antibodies; OE33 was used as an internal protein marker; dpi: days postinfestation.
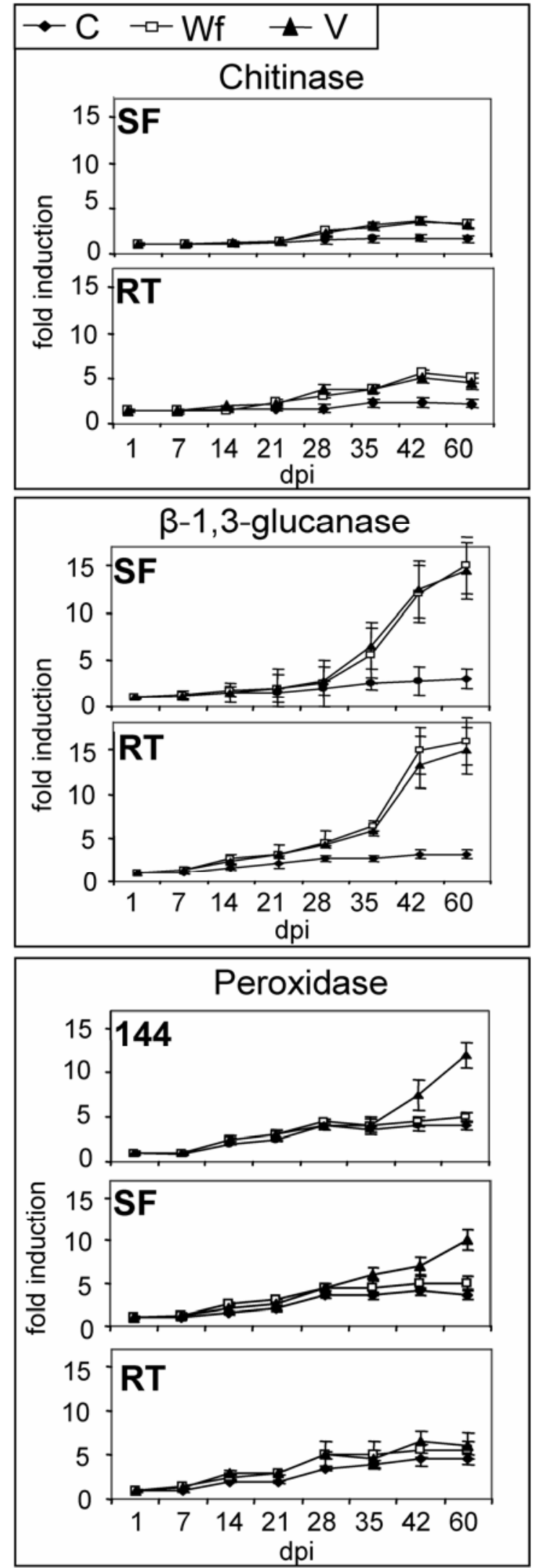

Fig. 4. Chitinase, $\beta$-1,3-glucanase, and peroxidase activities in susceptible (144 and SF) and resistant (RT) tomato plants following whitefly-mediated infestation. C: untreated, Wf: infestation with nonviruliferous whiteflies, $\mathrm{V}$ : infestation with viruliferous whiteflies. pathogenesis-related protein activities were measured from 1 to 60 days posttreatment. For chitinase and $\beta-1,3$-glucanase, the results obtained with SF were undistinguishable from those obtained with 144. Bars represent means and standard errors of four independent repeats; dpi: days postinfestation. 
not earlier then 4 to 5 weeks after the beginning of treatment), rot diseases caused by Sclerotinia sclerotiorum could be observed very shortly in different plants (Zhou and Boland 1998). Tomato leaves inoculated with mycelium-colonized fungal plugs started to show symptoms after 20 to $24 \mathrm{~h}$. The activities of all the PR proteins studied increased 2 days after Sclerotinia sclerotiorum inoculation (Fig. 5). Increased abundance of tomato ERK-like MAPK, HSP70, and HSP60 was observed as early as 1 day after fungal inoculation, followed by a rapid decline that coincided with the decline of total cellular proteins (shown for OE33, and observed for total Coomassie blue staining). Massive damage was observed 4 to 5 days after treatment. Virus-susceptible (SF and 144) and resistant (RT) tomato plants responded similarly to this kind of biotic stress.

\section{DISCUSSION}

Plants have evolved numerous defensive strategies to perceive and cope with aggression by pathogens, including insects and viruses. The domesticated tomato is extremely susceptible to whitefly-transmitted geminiviruses such as TYLCV. Early infected plants cease to grow, present characteristic symptoms of leaf yellowing and curling, and do not yield fruit. Breeding efforts have resulted in the development of resistant lines and commercial cultivars that present ameliorated symptoms and yields and a lower titer of virus than susceptible plants (Lapidot and Friedmann 2002). The biochemical features underlying the establishment of TYLCV resistance have not been studied. We have compared the patterns of proteins known to be involved in defense-like (PR proteins) and stress-like (HSPs and MAPKs) responses upon whitefly infestation and whiteflymediated inoculation of TYLCV in RT and SF tomato lines issued from the same breeding program. The genetically unrelated susceptible cv. 144 supported the results obtained with the SF line.

Biotic stresses, whitefly infestation, and whitefly-mediated inoculation of TYLCV do not cause extensive damage during the first 3 to 4 weeks after treatment. At these early stages, induction of the stress proteins ERK-like proteins and HSPs investigated in this study was not observed. On the contrary, the effects of whitefly infestation (viruliferous or not) can be summarized as a general decrease of most stress-like protein patterns in susceptible and resistant tomato lines. B. tabaci by itself leads to a decrease in the amounts of ERK-like proteins, HSPs, and chloroplast protease $\mathrm{FtsH}$, whereas ClpC amounts
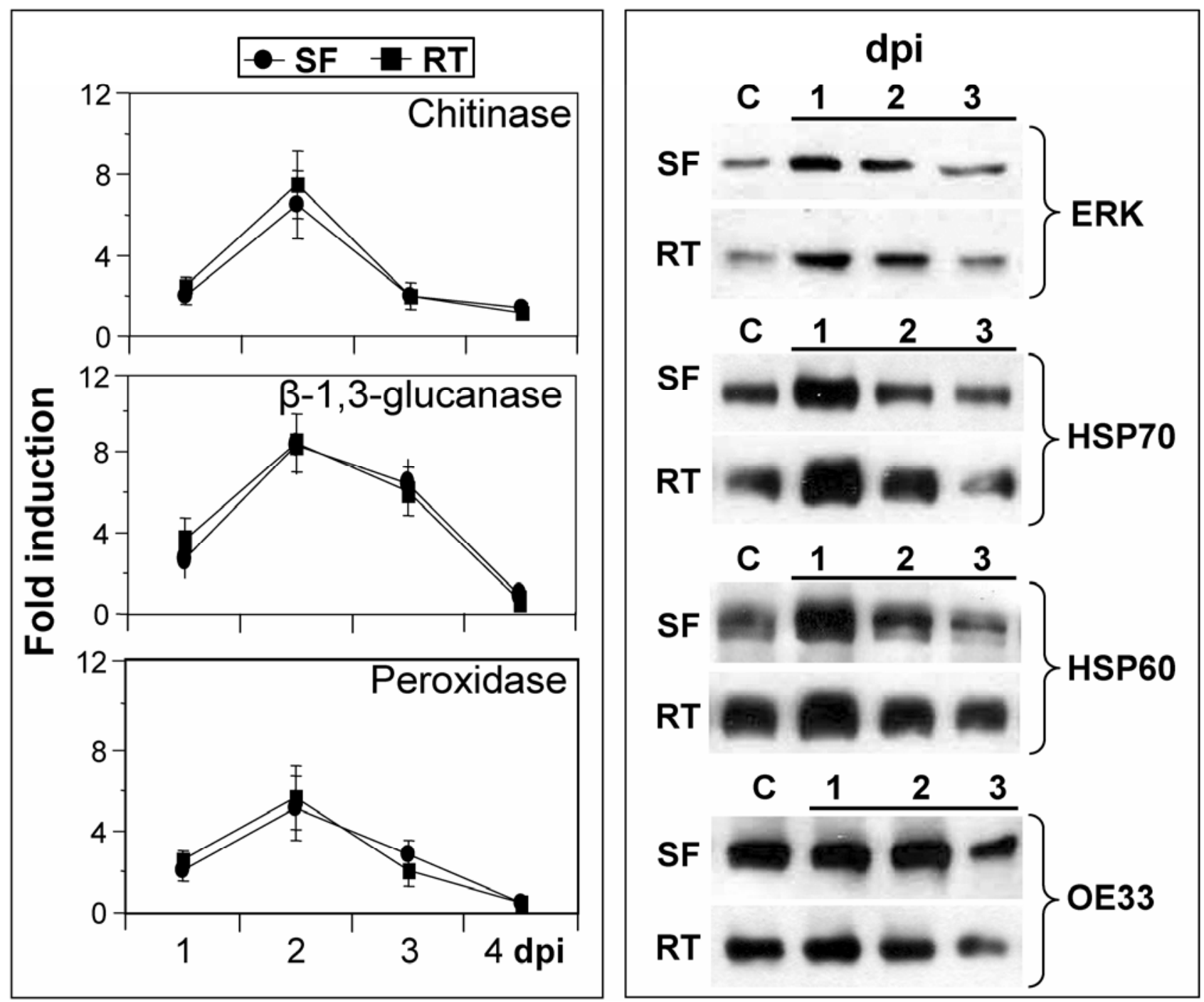

Fig. 5. Pathogenesis-related (PR) protein, mammalian extracellular signal-regulated kinase (ERK), and heat shock protein (HSP) profiles upon Sclerotinia sclerotiorum inoculation of the susceptible and resistant tomato lines SF and RT. Left panel: expression of PR proteins; bars represent means and standard errors of four independent repeats. Right panel: immunodetection of ERK-like proteins and HSPs using anti-ERK, anti-Hsp70/Hsc70 and anti-Hsp60 antibodies; dpi: days postinoculation. 
remained unchanged. TYLCV enhanced this effect, starting 2 weeks after inoculation, when the levels of total cellular proteins were still not affected (OE33). The decline in stress-response protein patterns upon inoculation was less pronounced in TYLCV-resistant than in TYLCV-susceptible plants, best seen at 10 to 15 dpi for ERK-like proteins, FtSH, and HSP70, indicating that these stress-response proteins, which may participate in the establishment of resistance, are subdued in SF (and 144) but not in RT genotypes.

PR enzyme activities increased significantly 4 weeks after inoculation and later. Insect and virus treatments led to a minor increase in chitinase activity; while a pronounced increase in $\beta$-1,3-glucanase activity was correlated solely with whitefly feeding. Susceptible and resistant plants behaved similarly upon treatments. In contrast, susceptible plants, but not resistant plants, challenged with viruliferous whiteflies showed a level of peroxidase significantly higher that that of mockinoculated leaves, correlated with the appearance of disease symptoms.

It is interesting to compare the effects of whiteflies on the host plant defense genes with those induced by other insects. Phloem-feeding whiteflies and aphids that produce little injury to plant foliage are perceived as pathogens and modulate the salicylic acid (SA)-dependent and jasmonic acid (JA)/ethylenedependent signaling pathways (Walling 2000; Zarate et al. 2007). Similarly, the analysis of sorghum (Sorghum bicolor) transcriptional changes induced by the phloem-feeding greenbug aphid (Schizaphis graminum) involved a strong induction of SA-regulated PR genes but a weak induction of wounding and JA-regulated genes (Zhu-Salzman et al. 2003). By comparison, chewing insects, such as caterpillars and beetles, and cell-content feeders, such as mites and thrips, cause more extensive tissue damage and activate wound-signaling pathways (Agrawal 1999; Duffey and Sout 1996; Reymond and Farmer 1998; Walling 2000).

Recently, in an attempt to understand how plants integrate stress-induced signals into specific defense responses, Arabidopsis plants were exposed to a set of pathogens with different modes of attack: the leaf bacterium Pseudomonas syringae pv. tomato, the leaf fungus Alternaria brassicicola, the tissuechewing caterpillar Pieris rapae, the cell-content-feeding thrips Frankiniella occidentalis, and the phloem-feeding aphid Myzus persicae (De Vos et al. 2005). Each of the Arabidopsisattacker combinations was accompanied by a complex set of alterations in mRNA abundance in which, in all cases, stressrelated genes were overrepresented. Comparison of the transcript profiles revealed that pathogens and insects with very different modes of action showed considerable overlap; however, at much less extent for $M$. persicae. Surprisingly, aphid feeding triggered the largest number of changes in mRNA levels, mostly gene downregulation, although they caused the least damage to the plant tissues. These genes were involved in plant metabolism and not directly in plant protection, such as PR proteins. The absence of detectable changes in SA, JA, and ethylene levels in host plant after 3 days of aphid feeding reflected the minor damage caused by this insect compared with the herbivorous caterpillar and the other pathogens (De Vos et al. 2005).

The observed decrease in the abundance of tomato stress proteins following whitefly infestation (viruliferous or not) can be considered as additional evidence for arthropod manipulation of plant defenses toward enhancement of insect performance on host plants (Thompson and Goggin 2006; Zarate et al. 2007; Zhu-Salzman et al. 2005). Plants pathogens, including whiteflies, produce effectors that antagonize defense signaling networks by suppressing expression of defense genes and altering turnover of defense regulatory proteins (Zarate et al.
2007). As a whole, the damage produced by phloem-feeding insects to plants is subtle and, consequently, induces unique responses in the host plant (De Ilarduya et al. 2003).

To emphasize the uniqueness of tomato response to whitefly infestation, another kind of biotic stress has been investigated. The effects of whitefly feeding and whitefly-virus-mediated transmission might resemble those obtained with the fungal pathogens (Zhu-Salzman et al. 2004). Sclerotinia sclerotiorum was used as an example of a fungal invader. It caused disease symptoms within a day, which is much faster than TYLCV. Sclerotinia sclerotiorum infection induced a sharp increase in PR protein enzymatic activities, which peaked 2 days after inoculation. Similarly, the fungi caused an increase in the abundances of phospho-ERK-like MAPK, HSP70, and HSP60 as early as 1 day after inoculation. No differences between the TYLCV-susceptible (SF or 144) and resistant (RT) tomato genotypes has been found in response to this biotic stress.

The effect of virus infection on host gene expression has been studied in most if not all cases by comparing transcript profiles before and after inoculation (Whitham et al. 2006), Viruses may alter plant gene expressions in ways that resemble stress and defense responses, inducing the accumulation of host gene products (Whitham et al. 2003). Plant response to geminiviruses in general and begomoviruses in particular has not been the object of many studies, despite their economic importance. In one study, Nicotiana megalosiphon was inoculated with the begomovirus Tomato mottle Taino virus (ToMoTV) by means of bombardment with DNA-coated particle (not whiteflies). Changes in transcript profiles occurring in the host plant in response to ToMoTV infection included genes encoding proteins related to defense, signal transduction, transport, metabolism, protein synthesis, and energy (Collazo et al. 2006). Another study indicated that infestation by whiteflies vectoring ToMoV induced much stronger PR protein expression than the virus-free whiteflies (McKenzie et al. 2002). However, this effect was acute only when the plants presented typical disease symptoms. In our study, among the PR protein activities assayed, only the induction of peroxidase in susceptible tomato plants could be correlated with TYLCV infection, albeit not earlier than 4 to 5 weeks after inoculation, when disease symptoms were clearly visible. We cannot exclude the possibility that there are additional PR proteins underlying resistance to TYLCV; for example, by restricting viral multiplication in the RT line. After exposure to whiteflies, whether viruliferous or not, the amounts of ERK-like proteins and HSP chaperone and protease studied decrease in the treated plants. The extent of depletion was more pronounced in the virus-susceptible SF and 144 than in the virus-resistant RT plants. The results presented here showed a correlation between abundance of several stress-response proteins and resistance upon TYLCV infection. It is possible that these proteins participate in the increased tolerance to whiteflies and TYLCV, not only in laboratory conditions but also in the field, by minimizing the damages insect feeding and viruses can induce.

\section{MATERIALS AND METHODS}

\section{Tomato genotypes.}

Two inbred tomato lines issued from the same breeding program aimed at introgressing resistance to TYLCV from Solanum habrochaites have been obtained (Vidavsky and Czosnek 1998): one is resistant to the virus (902) and the other is susceptible (906-4). The pedigree of the lines is shown in Vidavsky and Czosnek (1998). The two lines had Solanum lycopersicum characteristics and produced red fruit weighing between 80 and $120 \mathrm{~g}$. The TYLCV-susceptible commercial cv. Daniella (144) also was used in these studies. 
Maintenance of virus cultures, whiteflies, and plants.

Cultures of an Israeli isolate of TYLCV (Navot et al. 1991) were maintained in tomato plants (Solanum lycopersicum, cv. Daniella). Whiteflies, B. tabaci, B biotype, were reared on cotton plants (Gossypium hirsutum cv. Akala) grown in insectproof wooden cages at 24 to $27^{\circ} \mathrm{C}$ (Zeidan and Czosnek 1991). All experiments were conducted in insect-proof wooden cages kept at 24 to $27^{\circ} \mathrm{C}$ in an insect-proof growth chamber. TYLCV was acquired by whiteflies during a 48-h acquisition access period on TYLCV-infected tomato plants (at the five- to sevenleaf stage, 6 weeks after whitefly-mediated inoculation). The insects then were caged with test tomato plants at their fourleaf stage for 48- to 72-h inoculation access periods (approximately 30 insects per plant). Plants were mock inoculated with a similar number of nonviruliferous whiteflies for similar inoculation access periods. The plants were grown in an insectproof greenhouse kept at 18 to $24^{\circ} \mathrm{C}$, with a daily regimen of 8 $\mathrm{h}$ of light and $16 \mathrm{~h}$ of darkness.

\section{Plant inoculation with Sclerotinia sclerotiorum.}

The wild-type Sclerotinia sclerotiorum isolate 1980 was used in this study. Cultures were routinely maintained on potato dextrose agar (Difco Laboratories, Detroit). Tomato leaves were placed in glass dishes lined with water-saturated Whatman filter paper and inoculated with two $0.5-\mathrm{cm}$ mycelium-colonized agar plugs. Inoculation was maintained at $100 \%$ relative humidity at $18^{\circ} \mathrm{C}$ for 4 days. The experiment was performed with five leaves of each tomato line at least three times.

\section{Immunodetection of proteins.}

Five sets of plants (SF, 144, and RT) were tested during the 2 years of research. From each plant set and for each treatment (control, nonviruliferous, and viruliferous whiteflies), leaves of two plants were analyzed separately. Fresh tomato leaf tissues (100 mg/sample) were cut, frozen in liquid nitrogen, ground twice by a bead-beater $(4.5000 \mathrm{rpm}, 40 \mathrm{~s})$ in a standard loading polyacrylamide gel electrophoresis buffer with $2.5 \% 2-\beta$ mercaptoethanol (Laemmli 1970). The samples were boiled for $5 \mathrm{~min}$ and centrifuged for $40 \mathrm{~min}$ at $10,000 \times \mathrm{g}$. Equal volumes $(20$ to $30 \mu \mathrm{l})$ of protein extracts were separated by sodium dodecyl sulfate (SDS) polyacrylamide gel electrophoresis (7.5 to $12 \%$ ). Western blotting was performed by standard procedures. Antibodies used throughout this study included antiPhospho-p44/42 MAPK (Thr202/Tyr204), anti-Phospho-P38, and anti-Phospho-SAPK/JNK (Cell Signaling Technology, Inc., Danvers, MA, U.S.A.). Anti-Hsp70/Hsc70, anti-Hsp60, and anti-Hsp90 antibodies were purchased from Stressgen (Stressgen Biotechnologies, San Diego, CA, U.S.A.). Anti$\mathrm{ClpC}$, anti-FtsH, and anti-OE33 polyclonal antibodies were a gift of Prof. Z. Adam (The Hebrew University of Jerusalem, Israel). Goat peroxidase-coupled secondary antibody (Stressgen) incubation was followed by the enhanced chemiluminescence detection (Amersham, High Wycombe, U.K.).

\section{PR protein activities.}

Leaves collected before and after treatments (100 mg/sample) were quickly frozen in liquid nitrogen and stored at $-20^{\circ} \mathrm{C}$. Frozen tissues were homogenized with a drill in $1 \mathrm{ml}$ of cold $75 \mathrm{mM}$ Tris- $\mathrm{HCl}$ buffer, $\mathrm{pH}$ 7.5, containing $5 \mathrm{mM}$ EDTA, 5 mM EGTA, $0.3 \%$ Triton X100, 0.2\% SDS, and a protease inhibitor cocktail (Complete Mini, Roche Diagnostics, Mannheim, Germany). The homogenates were incubated in ice for $40 \mathrm{~min}$ and centrifuged at $10,000 \times g$ for $40 \mathrm{~min}$. Supernatants were used for enzymatic assays.

Chitinase activity was based on the determination of $p$-nitrophenyl cleaved from a chitin analogue substrate, $p$-nitrophenyl- $\beta$-d- $N, N^{\prime}$-diacetylchitobiose (PNP) (Chernin et al. 1997). Crude protein extracts and $10 \mu \mathrm{l}$ of PNP $(2 \mathrm{mg} / \mathrm{ml})$ were added to 50 $\mathrm{mM}$ acetate buffer $(\mathrm{pH} \mathrm{5.0)}$ to a total volume of $0.5 \mathrm{ml}$ and incubated for $2 \mathrm{~h}$ in a water bath at $37^{\circ} \mathrm{C}$. The reaction was terminated with $0.5 \mathrm{ml}$ of $0.2 \mathrm{M} \mathrm{Na}_{2} \mathrm{CO}_{3}$. Chitinase activity was measured at $410 \mathrm{~nm}$ as $\mu$ moles PNP produced per milligram of fresh tissue per hour or per milligram per milliliter of protein per hour. The initial chitinase activity in untreated leaves was $10 \pm 5 \mu \mathrm{mol} \mathrm{PNP} / \mathrm{mg}$ of leaf/h or $7.5 \pm 5 \mu \mathrm{mol} \mathrm{PNP} / \mathrm{mg}$ of protein $/ \mathrm{h}$, depending on the plant age at the beginning of treatment.

Peroxidase activity was assayed with phenol red as a substrate (Yedidia et al. 1999). The complete reaction mixture (1 $\mathrm{ml}, 37^{\circ} \mathrm{C}$ ) contained 20 to $30 \mu \mathrm{l}$ of crude plant protein extracts, $50 \mu \mathrm{l}$ of $0.2 \%$ phenol red, and $50 \mathrm{mM}$ sodium citrate $(\mathrm{pH} 4.2$ ). Reaction was initiated with $10 \mu \mathrm{l}$ of $1 \mathrm{mM}$ hydrogen peroxide and stopped after 3 min with $40 \mu \mathrm{l}$ of $2 \mathrm{~N} \mathrm{NaOH}$. Activity was measured at $610 \mathrm{~nm}$ as $\mu$ moles of phenol red oxidized per milligram of fresh tissue per minute or per milligram per milliliter of protein per minute. The initial peroxidase activity in untreated leaves was $1.75 \pm 1.5 \mu \mathrm{mol}$ phenol $\mathrm{red} / \mathrm{mg}$ of leaf $/ \mathrm{min}$ or $0.25 \pm$ $0.15 \mu \mathrm{mol} \mathrm{phenol} \mathrm{red} / \mathrm{mg}$ of protein $/ \mathrm{min}$, depending on the plant age at the beginning of treatment.

$\beta$-(1,3)-Glucanase activity assay was performed with 4-methylumbelliferyl $\beta$-D-glucose, dissolved in $0.5 \mathrm{M}$ potassium acetate buffer, pH $5.0(1.5 \mathrm{mg}$ in $5 \mathrm{ml}) ; 15 \mu \mathrm{l}$ of substrate was added to $30 \mu \mathrm{l}$ of crude protein extracts and incubated in enzyme-linked immunosorbent assay plates for 2 to $4 \mathrm{~h}$ at $37^{\circ} \mathrm{C}$ (Inbar and Chet 1994). The plates were scanned and analyzed with the ProGel program (Intas, Göttingen, Germany). The initial $\beta$-(1,3)-glucanase activity was taken as one unit in untreated tomato leaves.

Enzymatic assays were repeated in at least four independent experiments. PR proteins activities results are shown as fold change upon the different treatments.

\section{Statistical analyses.}

The activity of PR proteins in 144, SF, and RT lines was analyzed by the $r^{2}$ and analysis of variance tests, using the JMP statistical analysis package version 5.1. (SAS Institute, Cary, NC, U.S.A.).

\section{ACKNOWLEDGMENTS}

This research was supported by a grant from the USAID Middle East Research and Cooperation (MERC) program to H. Czosnek (GEG-G-0002-00003-00), project M21-037. We thank Z. Adam for antibodies against $\mathrm{ClpC}$, FtsH, and OE33 chloroplast proteins; A. Harel for the help in the experiments with Sclerotinia sclerotiorum; and S. Morin for help in statistical analyses (The Hebrew University of Jerusalem, Israel).

\section{LITERATURE CITED}

Adam, Z., and Clarke, A. K. 2002. Cutting edge of chloroplast proteolysis. Trends Plant Sci. 7:451-456.

Agrawal, A., A. 1999. Induced responses to herbivory in wild radish: Effects on several herbivores and plant fitness. Ecology 80:1713-1723.

Bogre, L., Meskiene, I., Heberle-Bors, E., and Hirt, H. 2000. Stressing the role of MAP kinases in mitogenic stimulation. Plant Mol. Biol. 43:705718.

Boston R. S., Viitanen, P. V., and Vierling, E. 1996. Molecular chaperones and protein folding in plants. Plant Mol. Biol. 32:191-222.

Chernin, L. S., De la Fuente, L., Sobolev, V., Oppenheim, A. B., and Chet, I. 1997. Molecular cloning, structural analysis, and expression in Escherichia coli of a chitinase gene from Enterobacter agglomerans. Appl. Environ. Microbiol. 63:834-839.

Collazo, C., Ramos, P. L., Chacón, O., Borroto, C. J., López, Y., Pujol, M., Thomma, B. P. H. J., Hein, I., and Borrás-Hidalgo, O. 2006. Phenotypical and molecular characterization of the Tomato mottle Taino virus-Nicotiana megalosiphon interaction. Physiol. Mol. Plant Pathol. 67:231-236. 
Czosnek, H., and Laterrot, H. 1997. A worldwide survey of tomato yellow leaf curl viruses. Arch. Virol. 142:1391-1406.

De Ilarduya, O. M., Xie, Q.-G., and Kaloshian, I. 2003. Aphid-induced defense responses in $\mathrm{Mi}$-1-mediated compatible and incompatible tomato interactions. Mol. Plant-Microbe Interact. 16:699-708.

Desikan, R., Hancock, J. T., Ichimura, K., Shinozaki, K., and Neill, S. J. 2001. Harpin induces activation of the Arabidopsis mitogen-activated protein kinases AtMPK4 and AtMPK6. Plant Physiol. 126:1579-1587.

De Vos, M., Van Oosten, V. R., Van Poecke, R. M., Van Pelt, J. A., Pozo, M. J., Mueller, M. J., Buchala, A. J., Metraux, J. P., Van Loon, L. C., Dicke, M., and Pieterse, C. M. 2005. Signal signature and transcriptome changes of Arabidopsis during pathogen and insect attack. Mol. PlantMicrobe Interact. 18:923-937.

Duffey, S. S., and Stout, M. J. 1996. Antinutritive and toxic components of plant defense against insects. Arch. Insect Biochem. Physiol. 32:3-37.

Fidantsef, A. L., Stout, M. J., Thaler, J. S., Duffey, S. S., and Bostock, R. M. 1999. Signal interactions in pathogen and insect attack: Expression of lipoxygenase, proteinase inhibitor II, and pathogenesis-related protein P4 in the tomato, Lycopersicon esculentum. Physiol. Mol. Plant. Pathol. 54:97-114

Grover, A. 2002. Molecular biology of stress responses. Cell Stress Chaperones $7: 1-5$.

Halperin, T., and Adam, Z. 1996. Degradation of mistargeted OEE33 in the chloroplast stroma. Plant Mol. Biol. 30:925-933.

Hirt, H. 1997. Multiple roles of MAP kinases in plant signal transduction. Trends Plant Sci. 2:11-15.

Inbar, J., and Chet, I. 1994. A newly isolated lectin from the plant pathogenic fungus Sclerotium rolfsii: Purification, characterization and role in mycoparasitism. Microbiology 140:651-7.

Laemmli, U. K. 1970. Cleavage of structural proteins during the assembly of the head of bacteriophage T4. Nature 227:680-685

Lapidot, M., and Friedmann, M. 2002. Breeding for resistance to whiteflytransmitted geminiviruses. Ann. Appl. Biol. 140:109-127.

Mayer, R. T., McCollum, T. G., McDonald, R. E., Polston, J. E. and Doostdar, H. 1996. Bemisia feeding induces pathogenesis-related proteins in tomato. Pages 179-188 in: Bemisia 1995: Taxonomy, Biology, Damage, Control and Management. D. Gerling and R. T. Mayer, eds. Intercept Ltd., Andover, Hants, U.K.

McKenzie, C. L., Shatters, R. G., Jr., Doostdar, H., Lee, S. D., Inbar, M. and Mayer, R. T. 2002. Effect of geminivirus infection and Bemisia infestation on accumulation of pathogenesis-related proteins in tomato. Arch. Insect Biochem. Physiol. 49:203-214.

Navot, N., Pichersky, E., Zeidan, M., Zamir, D., and Czosnek, H. 1991. Tomato yellow leaf curl virus: A whitefly-transmitted geminivirus with a single genomic molecule. Virology 185:151-161.

Nuhse, T. S., Peck, S. C., Hirt, H., and Boller, T. 2000. Microbial elicitors induce activation and dual phosphorylation of the Arabidopsis thaliana MAPK 6. J. Biol. Chem. 275:7521-7526.

Pieterse, C. M., and Van Loon, L. C. 1999. Salicylic acid-independent plant defense pathways. Trends Plant Sci. 4:52-58.

Reymond, P., and Farmer, E. E. 1998. Jasmonate and salicylate as global signals for defense gene expression. Curr. Opin. Plant Biol. 1:404-411.

Rick, C. M. 1976. Natural variability in wild species of Lycopersicon and its bearing on tomato breeding. Agraria 30:249-510.

Roberts, C. J., Nelson, B., Marton, M. J., Stoughton, R., Meyer, M. R., Bennett, H. A., He, Y. D., Dai, H., Walker, W. L., Hughes, T. R., Tyers, M., Boone, C., and Friend, S. H. 2000. Signaling and circuitry of multiple MAPK pathways revealed by a matrix of global gene expression profiles. Science 287:873-880.

Seo, S., Okamoto, M., Iwai, T., Iwano, M., Fukui, K., Isogai, A., Nakajima,
N., and Ohashi, Y. 2000. Reduced levels of chloroplast FtsH protein in tobacco mosaic virus-infected tobacco leaves accelerate the hypersensitive reaction. Plant Cell 12:917-932.

Sherman, M. Y., and Goldberg, A. L. 2001. Cellular defenses against unfolded proteins: A cell biologist thinks about neurodegenerative diseases. Neuron 29:15-32.

Sun, W., Van Montagu, M., and Verbruggen, N. 2002. Small heat shock proteins and stress tolerance in plants, Biochim. Biophys. Acta 1577:1-9.

Sung, D. Y., and Guy, C. L. 2003. Physiological and molecular assessment of altered expression of Hsc70-1 in Arabidopsis. Evidence for pleiotropic consequences, Plant Physiol. 132:979-987.

Thompson, G. A., and Goggin, F. L. 2006. Transcriptomics and functional genomics of plant defense induction by phloem-feeding insects. J. Exp. Bot. 57:755-766.

Van Loon, L. C. 1999. The families of pathogenesis-related proteins, their activities, and comparative analysis PR-1 type proteins. Physiol. Mol. Plant Pathol. 55:85-97.

van Loon, L. C., Rep, M., and Pieterse, C. M. 2006 Significance of inducible defense-related proteins in infected plants. Annu. Rev. Phytopathol. 44:135-162.

Vidavsky, F., and Czosnek, H. 1998. Tomato breeding lines immune and tolerant to tomato yellow leaf curl virus (TYLCV) issued from Lycopersicon hirsutum. Phytopathology 88:910-914.

Walling, L. L. 2000. The myriad plant responses to herbivores. J. Plant Growth Regul. 19:195-216.

Wang, W., Vinocur, B., Shoseyov, O., and Altman, A. 2004. Role of plant heat-shock proteins and molecular chaperones in the abiotic stress response. Trends Plant Sci. 9:244-252.

Whitham, S. A., Quan, S., Chang, H. S., Cooper, B., Estes, B., Zhu, T., Wang, X., and Hou, Y. M. 2003. Diverse RNA viruses elicit the expression of common sets of genes in susceptible Arabidopsis thaliana plants. Plant J. 33:271-283.

Whitham, S. A., Yang, C., and Goodin, M. M. 2006. Global impact: Elucidating plant responses to viral infection. Mol. Plant-Microbe Interact. 19:1207-1215.

Yedidia, I., Benhamou, N., and Chet, I. 1999. Induction of defense responses in cucumber plants (Cucumis sativus L.) by the biocontrol agent Trichoderma harzianum. Appl. Environ. Microbiol. 65:10611070

Yuasa, T., Ichimura, K., Mizoguchi, T., and Shinozaki, K. 2001. Oxidative stress activates ATMPK6, an Arabidopsis homologue of MAP kinase. Plant Cell Physiol. 42:1012-1016.

Zamir, D., and Eshed, Y. 1997. Tomato genetics and breeding using nearly isogenic introgression lines derived from wild species. Pages 207-217 in: Molecular Dissection of Complex Traits. A. H. Paterson, ed. CRC Press, Inc., Boca Raton, FL, U.S.A.

Zarate, S. I., Kempema, L. A., and Walling, L. L. 2007. Silverleaf whitefly induces salicylic acid defenses and suppresses effectual jasmonic acid defenses. Plant Physiol. 143:866-875.

Zeidan, M., and Czosnek, H. 1991. Acquisition of tomato yellow leaf curl virus by the whitefly Bemisia tabaci. J. Gen. Virol. 72:2607-2614.

Zhou, T., and Boland, G. J. 1998. Biological control strategies for Sclerotinia diseases. Pages 127-156 in: Plant-Microbe Interactions and Biological Control. G. J. Boland and L. D. Kuykendall, eds. Marcel Dekker, Inc., New York.

Zhu-Salzman, K., Salzman, R. A., Ahn J.-E., and Koiwa, H. 2006. Transcriptional regulation of sorghum defense determinants against a phloem-feeding aphid. Plant Physiol. 134:420-431.

Zhu-Salzman, K., Bi, J. L., and Liu, T. X. 2005. Molecular strategies of plant defense and insect counter-defense. Insect Sci. 12:315. 